\title{
The Endocrine Cells in the Gastroenteropancreatic System of the Bowfin, Amia calva L.: An Immunohistochemical, Ultrastructural, and Immunocytochemical Analysis
}

\author{
John H. Youson, ${ }^{1 \star}$ Azza A. Al-Mahrouki, ${ }^{1}$ Diana Naumovski, ${ }^{1}$ and J. Michael Conlon ${ }^{2}$ \\ ${ }^{1}$ Department of Zoology and Division of Life Sciences, University of Toronto at Scarborough, \\ Scarborough, Ontario, Canada \\ ${ }^{2}$ Department of Biomedical Sciences, Creighton University Medical School, Omaha, Nebraska
}

\begin{abstract}
The gastroenteropancreatic (GEP) endocrine system of bowfin (Amia calva) was described using light and electron microscopy and immunological methods. The islet organ (endocrine pancreas) consists of diffusely scattered, mostly small islets and isolated patches of cells among and within the exocrine acini. The islets are composed of abundant, centrally located B cells immunoreactive to bovine and lamprey insulin antisera and $\mathrm{D}$ cells showing a widespread distribution and specificity to somatostatin antibodies. A and F cells are present at the very periphery of the islets and are immunoreactive with antisera against glucagon (and glucagon-like peptide) and several peptides of the pancreatic polypeptide (PP)-family, respectively. The peptides of the two families usually collocates within the same peripheral islet cells and are the most common immunoreactive peptides present in the extra-islet tissue. Immunocytochemistry and fine structural observations characterised the granule morphology for B and D cells and identified two cell types with gran-
\end{abstract}

There has been a great deal of interest in recent years in defining both the primary structure and the distribution of regulatory peptides of the gastroenteropancreatic (GEP) system in fishes (for review see Youson and Al-Mahrouki, 1999). The primary peptides under investigation have been insulin, glucagon (GLU), and glucagon-like peptide (GLP), somatostatin (SST), and members of pancreatic polypeptide (PP) family, namely neuropeptide tyrosine (NPY), pancreatic polypeptide (PP), and peptide tyrosine tyrosine (PYY). The underlying objectives of studies concerned with isolation and description of the primary structure are to explain both the biological activity of these hormones within the organisms in question and to compare amino acid sequences so as to expand our knowledge of molecular evolution of regulatory peptides (Conlon, 1995; Larhammar, 1996; Plisetskaya and Mommsen, 1996). Immunohistochemistry has been the primary tool for identifying the distribution of the endocrine cells within the stomach, intestine, and the endocrine pancreas, while electron micros- ules immunoreactive to glucagon antisera. These two putative A cells had similar granules, which were distinct from either B or D cells, but one of the cells had rodshaped cytoplasmic inclusions within cisternae of what appeared to be rough endoplasmic reticulum. The inclusions were not immunoreactive to either insulin or glucagon antisera. Only small numbers of cells in the stomach and intestine immunoreacted to antisera against somatostatin, glucagon, and PP-family peptides. The paucity of these cells was reflected in the low concentrations of these peptides in intestinal extracts. The GEP system of bowfin is not unlike that of other actinopterygian fishes, but there are some marked differences that may reflect the antiquity of this system and/or may be a consequence of the ontogeny of this system in this species. J. Morphol. 250: 208-224, 2001. @ 2001 Wiley-Liss, Inc.

KEY WORDS: GEP; endocrine; pancreas; bowfin immunohistochemistry; ultrastructure

copy and immunocytochemistry have been useful in defining the characteristics of the cell types. The fish homologue to the endocrine pancreas of higher vertebrates is called the islet organ (which is also referenced as islet tissue, islets of Langerhans, Brockmann bodies, and principal islets), and is comprised of distinct cell types, each of which produces a different hormone. Within the Teleostei, the major group of bony fishes (class Osteichthyes), four cell types have been identified, namely: A cells, which produce glucagon; B cells, which produce insulin; D cells, which produce somatostatin; and $\mathrm{F}$ cells, which produce peptides of the PP family. Each cell

\footnotetext{
Contract grant sponsor: Natural Sciences and Engineering Research Council of Canada (J.H.Y.)

*Correspondence to: Dr. John H. Youson, Department of Zoology and Division of Life Sciences, University of Toronto at Scarborough, Scarborough, Ontario,Canada, M1C 1A4.

E-mail: youson@scar.utoronto.ca
} 
type has a relatively characteristic fine structure within, but not necessarily between, species. However, colocalisation of antibodies to PP and glucagon in the same cell type is common in some fishes (Abad et al., 1988; Lozano et al., 1991). It has been found that some of these peptides (namely glucagon- and PP-family peptides and SST) may also be present in cells of the gastrointestinal epithelia (Elbal et al., 1988; Nozaki et al., 1988).

The Holostei are an ancient group of actinopterygian (ray-finned) bony fishes, and present classification has divided the extant representatives into the orders Amiiformes and Semiontiformes. Recently, we examined the GEP system of a semiontiforme, the gar (Lepisosteus osseus), using light and electron microscopy, and immunohistochemical and immunocytochemical procedures (Groff and Youson, 1997, 1998). We found only three definitive cell types, B, $\mathrm{D}$, and $\mathrm{A} / \mathrm{F}$ cells within the islet organ, with the latter type colocalising two peptides. This finding was novel among bony fishes and may reflect an ancient character of the actinopterygians. Bowfin, Amia calva, has been of particular interest to our studies of the evolution of regulatory peptides in fishes, for ancient Amiiformes are suspected to have given rise to the more recent actinopterygians, the teleosts (Gardiner et al., 1996). We have provided data from bowfin on the primary structure of insulin (Conlon et al., 1991a), a PP-family peptide (Conlon et al., 1991b), two SSTs (Wang et al., 1993), and both GLU and GLP (Conlon et al., 1993). In summary, we found the PP-family peptide to be most like mammalian PYY, insulin to have some unique amino acid substitutions, post-translational processing of prosomatostatin-I to be different from teleosts and higher vertebrates (Conlon et al., 1991b), GLU to be relatively conserved, and GLP to have 15 amino acid substitutions and three deletions when compared to human GLP-1-(7-37)-peptide (Conlon et al., 1993). Consistent with these findings were the observations that in comparison to the situation in their mammalian counterparts, bowfin insulin is much less efficient in inhibiting the binding of human ${ }^{125}$ I-insulin to the human insulin receptor (Conlon et al., 1991a), and bowfin GLP is three-fold less effective and 23-fold less potent in stimulating glycogenolysis in the copper rockfish (Conlon et al., 1993).

There have been reports of the distribution of the islet organ of bowfin as consisting of diffusely scattered islets accompanying the abdominal blood vessels and bile ducts (Epple and Brinn, 1975, 1986). A preliminary ultrastructural investigation has indicated four major cell types, probably A, B, D, and F (Epple and Brinn, 1975; Falkmer, 1985). There have been no detailed descriptions of the identification and distribution of endocrine cells of the islet organ, stomach, and intestine in the bowfin using immunohistochemical procedures, although we presented some preliminary findings in a recent review (Youson and Al-Mahrouki, 1999). The present study ex- amines the cell types within the islet tissue of the bowfin pancreas through immunohistochemistry, routine transmission electron microscopy, and immunocytochemistry. In addition, we report on our attempt to describe the distribution of endocrine cells in tissue sections of stomach and intestine, as well as correlating the information on the concentration of regulatory peptides in extracts of bowfin intestine with the immunohistochemical data.

\section{MATERIALS AND METHODS Animals}

Bowfin, A. calva, were collected from Hay Bay of Lake Ontario near Napanee, Ontario by local fishermen. The animals were transported to the University of Toronto at Scarborough where they were held in fibre glass tanks for 1-4 weeks before they were anaesthetised in tricaine methanesulfonate and killed by decapitation. Fifteen animals, 35-65 cm long and of both sexes, were used in the histological studies and 20 animals were used for peptide extraction.

\section{Tissue Preparation}

Routine light microscopy. For general light microscopy, a portion of the viscera of two animals that included the caudal part of the liver, the gall bladder, the extrahepatic common bile duct, the stomach, the proximal (anterior) part of the intestine, and the surrounding mesentery was removed and fixed intact in Bouin's fluid for $48 \mathrm{~h}$. Following storage in $70 \%$ ethanol, this large mass was mapped and divided into smaller sections for embedding in tissue-prep paraffin. Serial sections of each tissue block were cut at a thickness of $7 \mu \mathrm{m}$ and stained with either the periodic acid-Schiff procedure, acid haemalum, and orange G, or haematoxylin and eosin. Slides were subsequently examined for the presence of pancreatic tissue and the distribution of the islet (islet organ) tissue was described (Fig. 1).

Immunohistochemistry. On the basis of the results of the above analysis, a portion of the viscera that included the upper portion of the anterior intestine and the adjoining mesentery was removed, fixed in Bouin's fluid for $24 \mathrm{~h}$, and processed for use in light microscopic immunohistochemistry. A portion of the posterior intestine was also similarly processed. Paraffin sections were cut at a thickness of 4-6 $\mu \mathrm{m}$ and mounted on glass slides. The following antisera were used in this study: guinea pig antibovine insulin (anti-m-INS, a kind gift of Dr. C. Yip, University of Toronto) diluted 1:1000; rabbit antisalmon insulin (anti-s-INS, Plisetskaya et al., 1985) diluted 1:1000; rabbit antilamprey insulin (antil-INS, Plisetskaya et al., 1988) diluted 1:1000; antisynthetic somatostatin-14 (anti-SST-14, Cheung et al., 1990) diluted 1:1000; rabbit antisalmon somatostatin-25 (anti-SST-25, courtesy of Dr. E. M. Pli- 


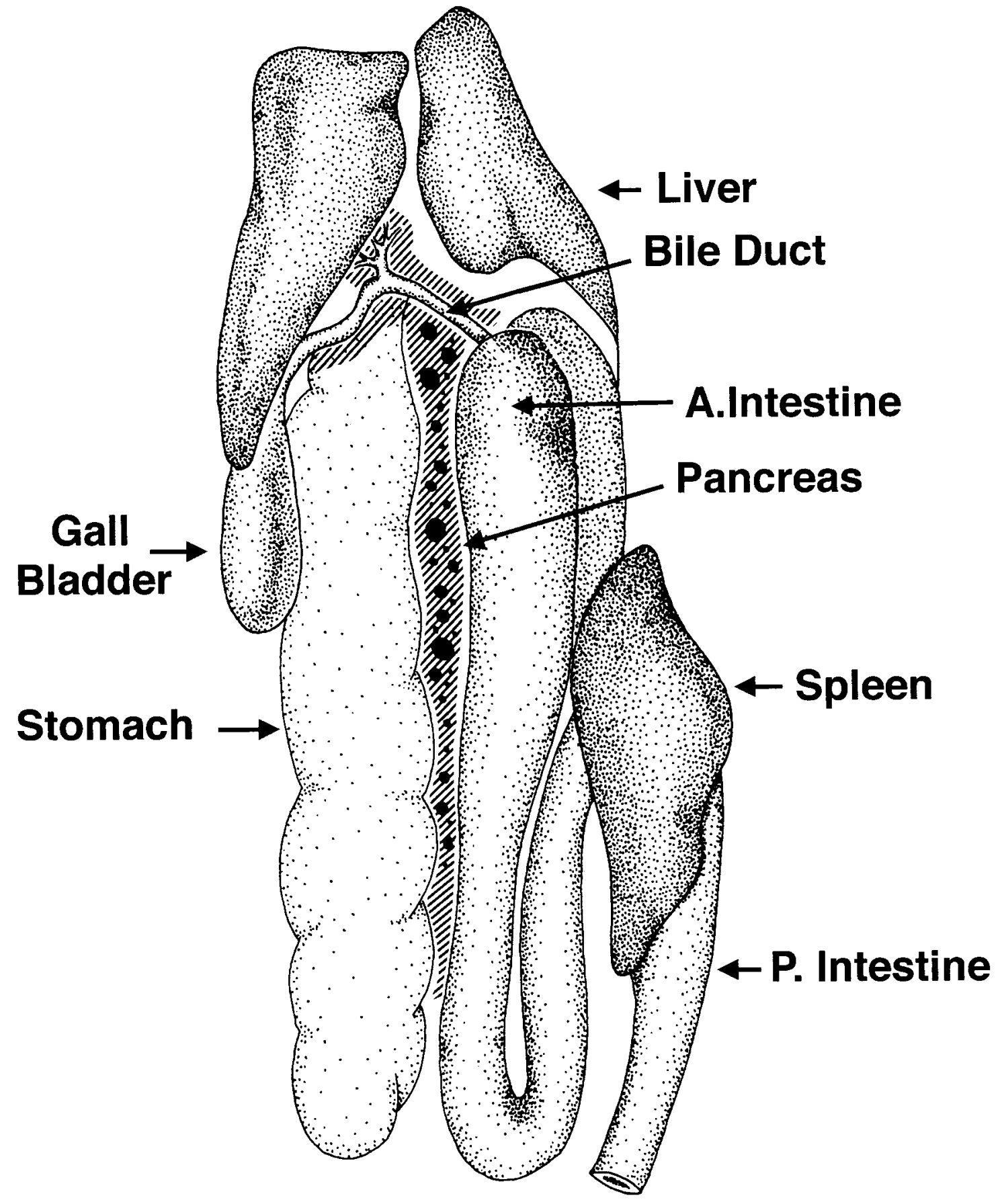

Fig. 1. Diagrammatic representation of the distribution of the islets (dark circles of various sizes) among the acini (crosshatched areas) of the pancreas of bowfin, Amia calva. The distribution of pancreatic tissue is shown relative to the viscera as labelled. A: Intestine, anterior intestine with arrow traversing a portion of the stomach below; P: Intestine, posterior intestine.

setskaya, University of Washington) diluted 1:1000; rabbit antiporcine glucagon (anti-GLU, Zymed Laboratories, Inc., San Francisco, CA); rabbit antisalmon glucagon-like peptide (anti-GLP, E. M. Plisetskaya) diluted $1: 1000$; rabbit antisynthetic glycine-extended anglerfish polypeptide Y (antiaPY, courtesy of P. C. Andrews, University of Mich- igan) diluted 1:1000; rabbit antihuman neuropeptide Y (anti-NPY, P. C. Andrews) diluted 1:1000; and rabbit antisalmon polypeptide tyrosine tyrosine (anti-PYY, E.M. Plisetskaya) diluted 1:1000.

Immunostaining was performed using either the peroxidase-antiperoxidase (PAP) technique of Sternberger et al. (1970), or a commercial kit (SP kit, 
Zymed-Lab-SA System) at room temperature (RT). Briefly, using the PAP technique, tissue sections were: incubated at room temperature for $20 \mathrm{~min}$ with phosphate-buffered saline (PBS) and 3\% heat inactivated goat serum (HIGS) [in the case of antim-INS, HIGS was replaced with heat inactivated rabbit serum (HIRS)]; incubated at $4^{\circ} \mathrm{C}$ for $48 \mathrm{~h}$ in the primary antiserum diluted with PBS; rinsed in PBS and 1\% HIGS/HIRS for 20 min; incubated in a secondary antisera (goat antirabbit or goat antiguinea pig) diluted 1:50 for $30 \mathrm{~min}$; washed in PBS-1\% HIGS/HIRS and then incubated in the same solution for $20 \mathrm{~min}$; incubated with PAP (guinea pig or rabbit system) at 1:50 for $30 \mathrm{~min}$; washed in PBS-1\% HIGS/HIRS, TRIS buffer ( $\mathrm{pH}$ 7.6) for $15 \mathrm{~min}$; incubated in $0.003 \%$ hydrogen peroxide and $0.0125 \% 3,3^{\prime}$ diaminobenzidine tetrahydrochloride for $15 \mathrm{~min}$; the slides were exposed to $1 \%$ osmium tetroxide for $1 \mathrm{~min}$ and a distilled water wash before dehydration and mounting. Positive immunoreactivity of unknown samples was denoted by a brown precipitate.

The commercial kit used a biotinylated second antibody, a horse radish peroxidase-streptavidin conjugate, and a substrate-chromogen. Positive staining was indicated by red coloration while haematoxylin was the counterstain. The specificity of the various antisera was tested with positive and negative controls. Sections of mouse brain (antiNPY), anglerfish Brockmann bodies (anti-aPY), and intestine (anti-GLU, anti-GLP), and either caudal principal islet of juvenile sea lampreys (Petromyzon marinus) or islet tissue of teleosts (Al-Mahrouki and Youson, 1998) for all anti-insulins and anti-SSTs were used in conjunction with experimental slides to verify positive immunoreactivity. Staining was abolished when the primary antibody was replaced with either PBS and HIGS/HIRS or with preimmune rabbit and guinea pig serum. In a few cases (anti-SST14 , anti-m-INS), staining was abolished by absorption of antisera with excess antigen prior to its application.

Double labelling was performed with two groups of antisera: anti-SST-14 and anti-SST-25; anti-GLU and either anti-NPY or anti-aPY. The Histostain-DS kit (Zymed Laboratories) was applied; this kit uses the Labeled-(strept)Avidin-Biotin (LAB-SA) method, also known as Streptavidin-Biotin Amplification. Two distinct substrate/chromogen/enzyme systems are used: hydrogen peroxide/AEC/peroxidase, which produces an intense red, and BCIP/NBT/alkaline phosphatase, which produces a dark purple stain. In the tests of both groups of antisera, the immunoreactions on tissue sections were repeated using alternate chromogens with the antisera from the preceding test.

Routine electron microscopy. Pancreatic tissue located in the mesentery adjacent to the anterior intestine was removed from six bowfin, diced into three 1-mm pieces, and fixed at room temperature in $4 \%$ paraformaldehyde- $0.1 \%$ glutaraldehyde in $0.1 \mathrm{M}$ phosphate buffer at $\mathrm{pH} 7.4$ for $1 \mathrm{~h}$. Some of these pieces were processed for immunocytochemistry as described below, but the majority were washed several times in the buffer and then postfixed in $1 \%$ osmium tetroxide in the same buffer for $1 \mathrm{~h}$ at $4^{\circ} \mathrm{C}$. Following several buffer washes, the tissues were dehydrated and embedded in an Epon/araldite mixture or Spurr's resin. Thin sections were cut with glass knives on a Reichert ultracut ultramicrotome, mounted on uncoated copper grids, stained with uranyl acetate and lead citrate, and examined in a Siemens Elmiskop 102 electron microscope.

Immunocytochemistry. Following the primary fixation and buffer washes some pieces of tissue were dehydrated and embedded in Epon/araldite or Spurr's resins. Ultrathin sections were cut and placed on uncoated nickel grids and protein A-gold labelling for insulin was carried out according to the method of Bendayan (1989), as follows: The grid was placed (section side down) in PBS-1\% ovalbumin for 5 min at RT; the blotted grid was placed on a drop of antiserum, diluted to either 1:100, 1:300, 1:500, $1: 800,1: 1000,1: 1500$, or $1: 2000$ with PBS, for a $14-18 \mathrm{~h}$ incubation at $4^{\circ} \mathrm{C}$ in a moist chamber; there were six washes in PBS at 5 min each at RT; the grid was incubated in PBS-1\% albumin for 5 min at RT; the blotted grid was transferred to protein-A gold complex (20 nm particle size) diluted 1:30 with PBS-1\% ovalbumin for $1 \mathrm{~h}$ at RT; repeated washes as in step 3 and rinsing in distilled $\mathrm{H}_{2} 0$ were carried out; dried grids were lightly stained with uranyl acetate $(10 \mathrm{~min})$ and lead citrate $(2 \mathrm{~min})$. Controls consisted of replacing the antiserum with PBS, using the antiserum preabsorbed with excess antigen, or substituting the antisera with antisalmon stanniocalcin (a totally irrelevant antibody).

Tissue extraction. Small intestine (between 142 and $276 \mathrm{~g}$ ) taken from 13 adult specimens of bowfin of both sexes (length $35-65 \mathrm{~cm}$ ) was stored frozen at $-70^{\circ} \mathrm{C}$. The tissues were separately extracted while still frozen by homogenisation with 10 volumes of ethanol/0.7 M HCL (3:1 v/v) using a Waring blender. The homogenates were stirred for $2 \mathrm{~h}$ at $0^{\circ} \mathrm{C}$, and then centrifuged at $4,000 \times \mathrm{g}$ for $30 \mathrm{~min}$ at $40^{\circ} \mathrm{C}$. Ethanol was subsequently removed from the supernatant under reduced pressure. Following a second centrifugation under the same conditions, the extracts were separately pumped at a flow rate of 2 $\mathrm{ml} / \mathrm{min}$ through eight Sep-Pak C18 cartridges (Waters Associates) connected in series. Bound material was eluted with $70 \%$ (v/v) acetonitrile/water and lyophilised. The intestinal extracts, after partial purification on Sep-Pak cartridges, were redissolved in $1 \%(\mathrm{v} / \mathrm{v})$ trifluoroacetic acid/water $(10 \mathrm{ml})$ and chromatographed on a Biogel P-10 gel permeation column $(5 \times 100 \mathrm{~cm}$; Bio-Rad, Richmond, CA) equilibrated with $1 \mathrm{M}$ acetic acid at a flow rate of $72 \mathrm{ml} / \mathrm{h}$. Absorbance was measured at $280 \mathrm{~nm}$ and fractions $(12 \mathrm{ml})$ were collected. The concentration of regula- 
TABLE 1. Relative abundance of endocrine cells immunostaining with antisera against various peptides within the pancreas, intestine, and stomach of Amia calva

\begin{tabular}{|c|c|c|c|c|c|c|c|c|c|c|}
\hline \multirow[b]{2}{*}{ Tissue region } & \multirow[b]{2}{*}{ Cell } & \multicolumn{9}{|c|}{ Antisera } \\
\hline & & m-INS & 1-INS & SST-14 & SST-25 & NPY & $\mathrm{aPY}$ & PYY & GLU & GLP \\
\hline \multicolumn{11}{|l|}{ Pancreas } \\
\hline \multirow[t]{4}{*}{ Islets } & A & - & - & - & - & - & - & - & +++ & + \\
\hline & $\mathrm{B}$ & +++ & +++ & - & - & - & - & - & - & - \\
\hline & $\mathrm{D}$ & - & - & ++ & ++ & - & - & - & - & - \\
\hline & $\mathrm{F}$ & _- & - & - & - & ++ & ++ & ++ & - & - \\
\hline Extra-islet cells & & ++ & - & + & + & ++ & ++ & + & ++ & ++ \\
\hline Anterior intestine & & - & - & - & ++ & ++ & - & ++ & - & + \\
\hline Posterior intestine & & - & - & - & ++ & - & - & - & +++ & - \\
\hline Stomach & & - & - & - & ++ & - & - & + & + & + \\
\hline
\end{tabular}

Relative abundance of staining/cells: +++ , more abundant; ++, abundant; +, less abundant; -, absent. a, anglerfish; l, lamprey; m, mammal. Abundance was assessed within the pancreas, intestine, and stomach and not between regions of the GEP system.

tory peptides in the fractions was determined by radioimmunoassay (RIA) at a dilution of 1:30.

RIA procedures. NPY was measured using antiserum 8995, which was raised against the synthetic COOH-terminal hexapeptide of human NPY (Cys-Ile-Thr-Arg-Gln-Arg-Tyr-NH2) in a RIA procedure that has been described by O'Hare and Schwartz (1989). The antiserum shows full crossreactivity with human NPY and PYY. Somatostatin was measured using antiserum G26 that was directed against the central region of SST-14 and which showed full reactivity with SST-28 (McIntosh et al., 1978). Glucagon-like immunoreactivity was measured with an antiserum directed against a site in the N-terminal region of porcine glucagon that cross-reacted with porcine glicentin (enteroglucagon) (Conlon and Thim, 1985).

\section{RESULTS \\ General Morphology}

Our observations confirm a previous report (Epple and Brinn, 1975) that said that bowfin pancreas is diffusely scattered in the mesentery that connects the liver, gall bladder, extrahepatic common bile duct, stomach, and the anterior intestine (Fig. 1). Pancreatic tissue was found to be most concentrated around the blood vessels and the bile duct within this mesentery, but some accompanied the latter and the hepatic portal vein for a short distance into the liver. This pancreatic tissue consisted of exocrine acini and accompanying intralobular and interlobular ducts and islets of endocrine cells of various sizes. The latter constituted the islet organ as defined by Youson and Al-Mahrouki (1999). There was no major concentration of islets (i.e., no Brockmann bodies), and although some islets were large, there were none that could be considered as principal islets (Youson and Al-Mahrouki, 1999). The intrahepatic pancreatic tissue was usually devoid of islets. In both haematoxylin and eosin and periodic acidSchiff (PAS) preparations the islets could be distinguished from the surrounding exocrine acini by their rich supply of capillaries among lighter staining epithelial cells. Endocrine cell types were not distinguishable with these staining procedures, but a strong PAS reaction (data not shown) was noted in the cytoplasm of many cells. The exocrine acinar cells had apical granules with a pronounced acidophilia and a basophilic basal cytoplasm, while ductular epithelium was composed of pale-staining cells.

Both the anterior and posterior intestine and the stomach possessed a simple columnar or pseudostratified epithelium of densely packed cells that covered elevations of the submucosa. These longitudinal folds were particularly pronounced in the posterior intestine. Gastric glands extended into the submucosa of the stomach. The tunica muscularis was comprised of smooth muscle.

\section{Immunohistochemistry}

A summary of the results of the immunohistochemical study is provided in Table 1. Immunohistochemistry was most useful in showing the islet tissue, for immunoreactivity revealed a more widespread distribution of endocrine cells than was anticipated based on our routine light microscopic observations. Although there were some large islets, there were many small aggregations of immunopositive cells among the exocrine acini that we assumed were small islets. Sampling of islets throughout their area of distribution did not reveal any regional variation in immunostaining. The antiserum to m-INS (Figs. 2A, 3C) revealed that a high concentration of B cells populates the central portion of each islet, and these cells seldom extend to the periphery of the islet. It was estimated that B cells might be as high as $80 \%$ of the cell population in some islets (Fig. 2A), with $60 \%$ being the lower limit (Fig. 3C). Anti-s-INS did not stain the islets, but this antibody was also weak in the positive control tissue. Absorption of the anti-m-INS with bovine insulin resulted in no staining of an adjacent section. The second most populous cell type was the $\mathrm{D}$ 

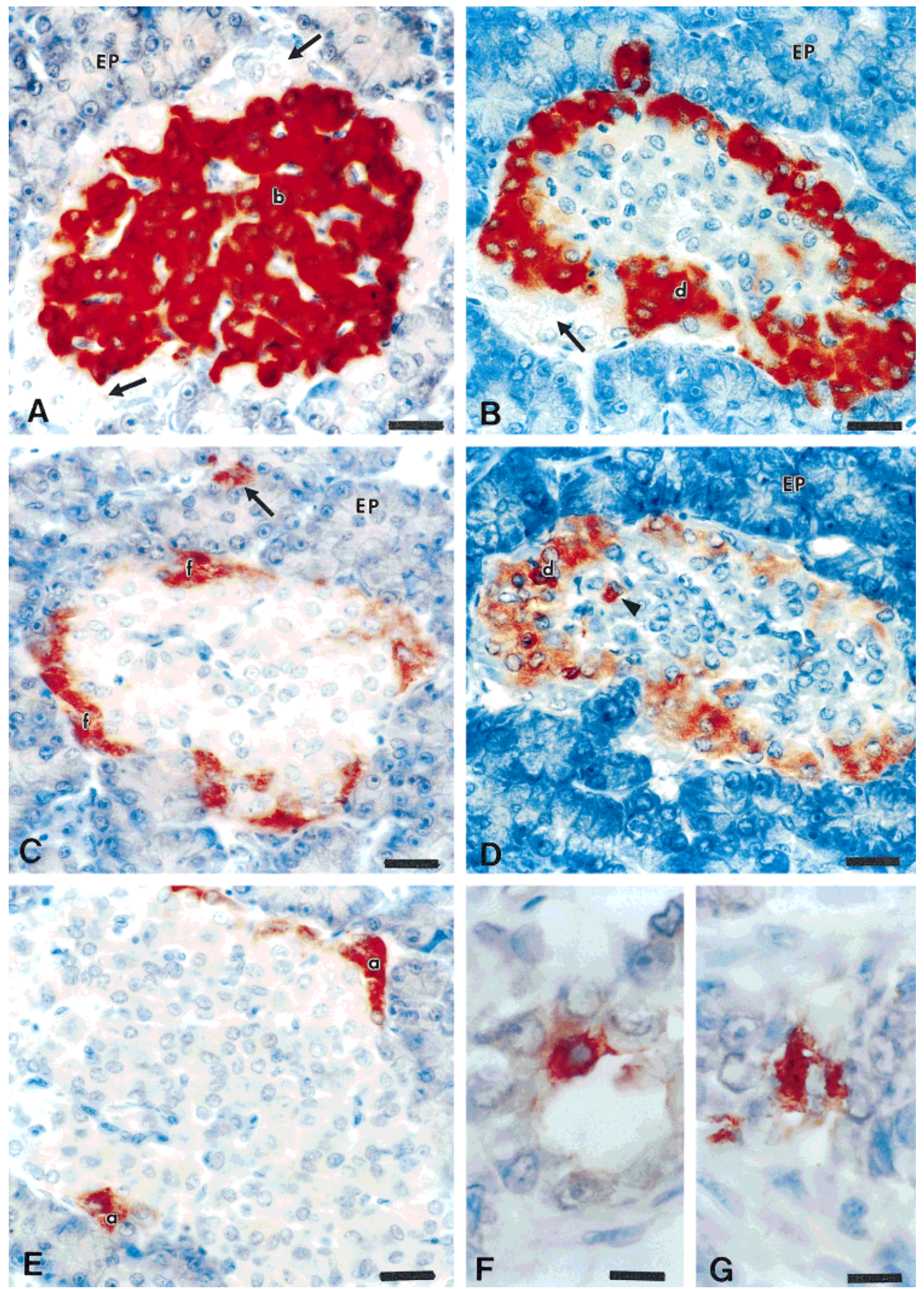

Fig. 2. Immunohistochemistry of cells of the GEP system of bowfin (Amia calva) using various antisera and the biotin-streptavidin process. Positive staining is indicated by red coloration while haematoxylin is the counterstain. A: An islet immunostained with anti-mINS shows B cells (b) confined to the centre of an islet and surrounded by a thick rim of immuno-negative cells (arrows). EP: exocrine acini. B: D cells (d), indicated by anti-SST 25 immunoreactivity, are distributed near the periphery of the islet but do not make up all peripheral cells (arrow). C: F cells (f), indicated by immunostaining with anti-aPY, are present in the periphery of the islet and between the acini (arrow). D: Some of the peripheral cells (d) and a few more central cells (arrowhead) in an islet immunostain with anti-SST 14. E: Only a few peripheral cells (a) in an islet immunostain with anti-GLP. F: A cell within a gastric gland of the stomach reacts positively with anti-GLU. G: A cell within the anterior intestinal epithelium reacts with anti-GLP. Bars: $\mathbf{A}, \mathbf{B}, \mathbf{C}, \mathbf{D}$, and $\mathbf{E}=$ $28 \mu \mathrm{m} ; \mathbf{F}, \mathbf{G}=11 \mu \mathrm{m}$. 

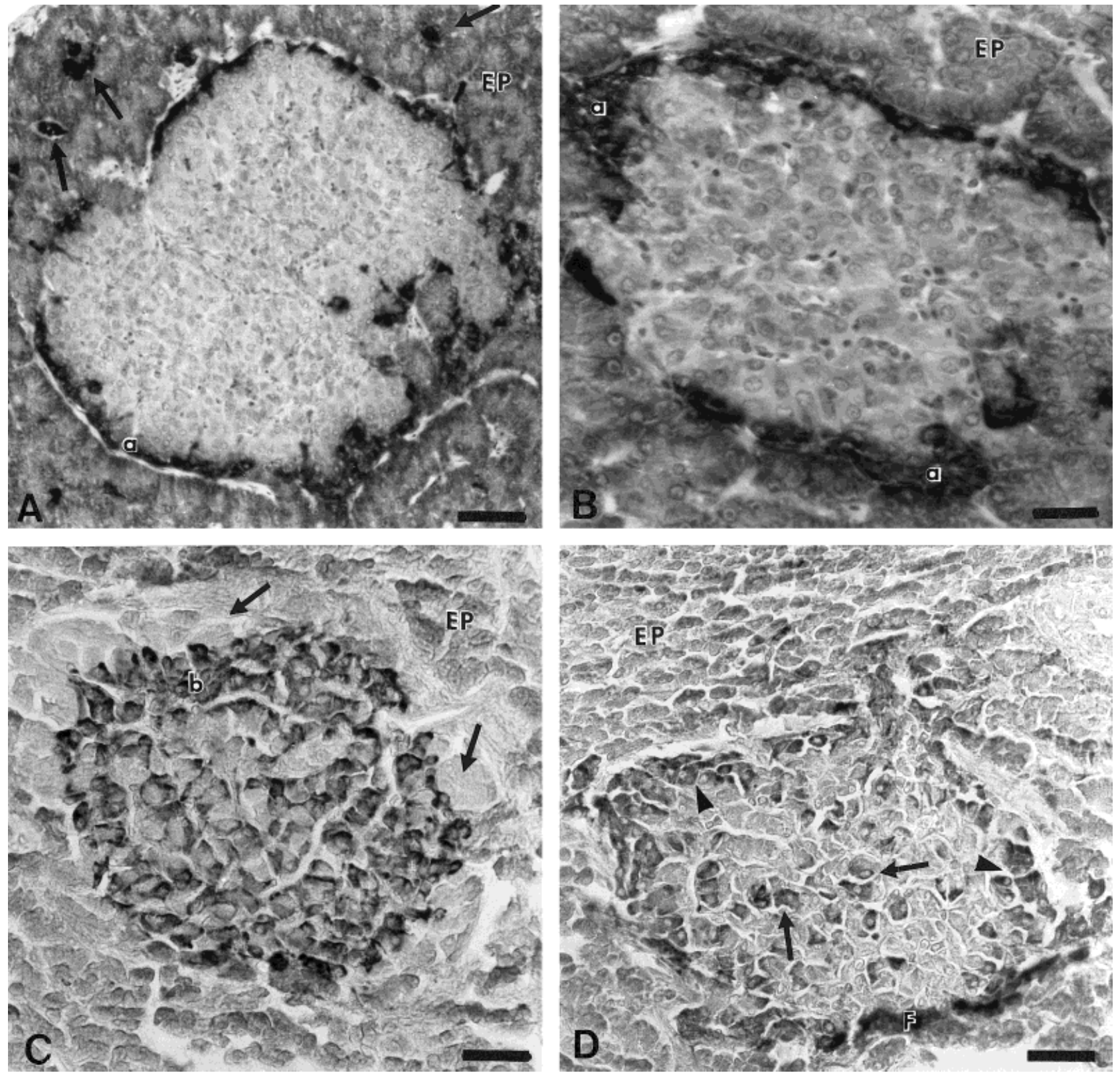

Fig. 3. Immunohistochemistry of pancreatic tissue of bowfin (Amia calva) with the biotin-streptavidin (A and B) and the peroxidase-antiperoxidase $(\mathbf{C}$ and $\mathbf{D})$ techniques shows the distribution of immunoreactive cell types in the islet and among the exocrine (EP) acini. Sections $\mathbf{A}$ and $\mathbf{B}$ were both immunostained with anti-GLU, but the former shows a thin rim of peripheral A cells (a) in the islet and others among the acini (arrows). Section B has A cells in peripheral clumps. C: B cells (b) are distributed in the central portion of the islet and are surrounded by a peripheral group of cells (arrows) nonreactive to anti-mINS. D: A section almost adjacent to that in $\mathbf{C}$ is immunostained with anti-SST 14 to show D cells (arrows) present among the B cells and also at the periphery (arrowheads). F: nonspecific staining due to a fold in the section. Bars: $\mathbf{A}=55 \mu \mathrm{m} ; \mathbf{B}=28 \mu \mathrm{m} ; \mathbf{C}$ and $\mathbf{D}=36 \mu \mathrm{m}$.

cell, which was identified through positive immunoreactivity with anti-SST-14 and anti-SST-25 (Figs. 2B,D, 3D). Immunostaining of $\mathrm{D}$ cells did not occur when either anti-SST-14 was preabsorbed with SST-14 or when anti-SST-34 was the primary antibody. The antisera to the SSTs revealed a diffuse distribution of cells throughout the islet that was not the same as the distribution of B cells (compare close to adjacent sections in Fig. 3C,D). Double im- munolabelling showed immunoreaction to antiSST-14 and anti-SST-25 in the same cells (Fig. $4 \mathrm{~A}, \mathrm{~B})$. Colocalisation of immunoreactivity to antiNPY, anti-PYY, and anti-aPY was found in F cells located at the very periphery of each islet (Fig. 2C). Cells immunostaining with these three antisera represented the smallest population of islet cells. Cells immunoreactive with anti-NPY and anti-aPY were also present among the acini (Fig. 2C). Strong im- 

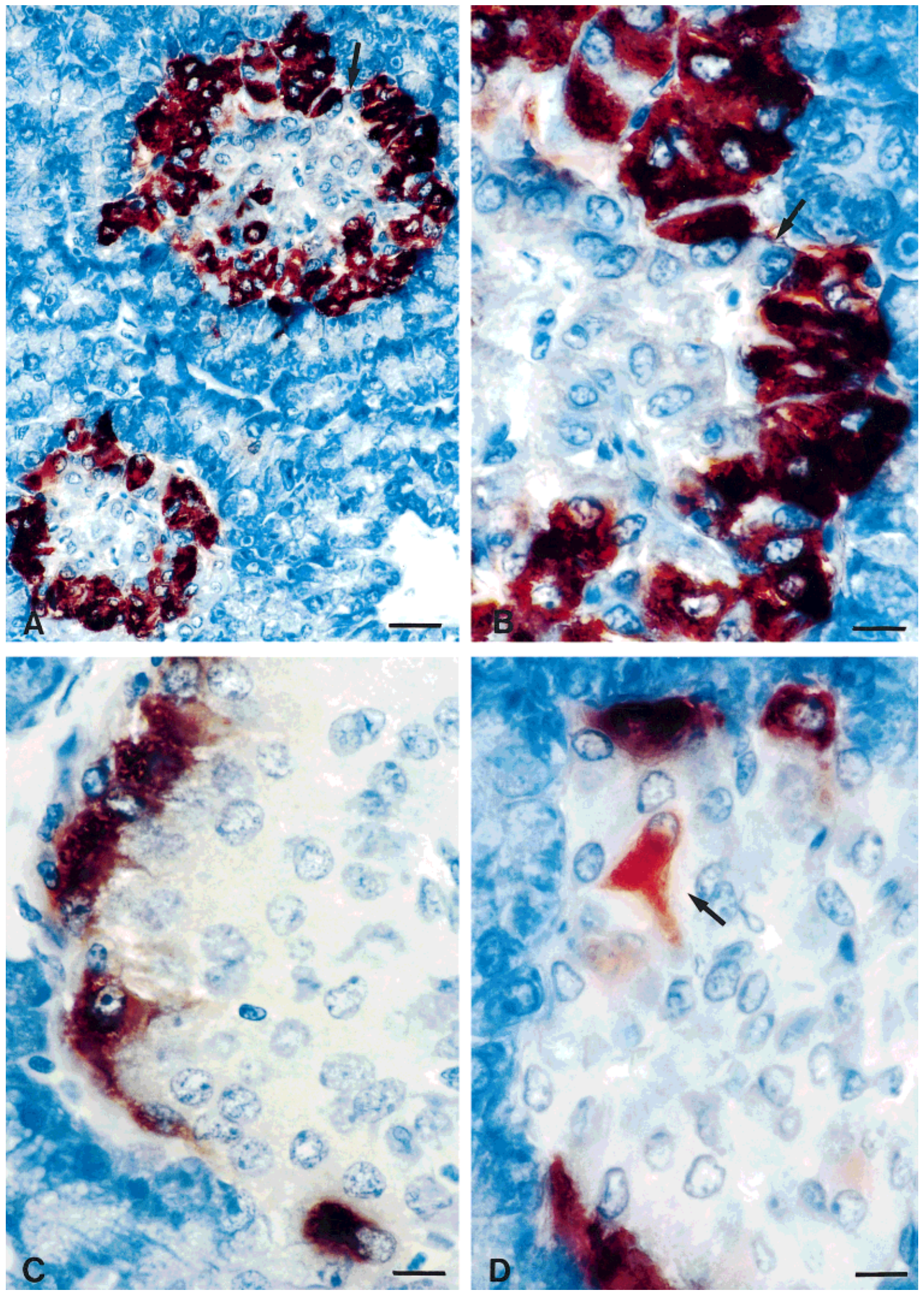

Fig. 4. Double immunolabelling of islet cells from the pancreas of bowfin (Amia calva). A: Two islets, surrounded by exocrine acini, have cells near the periphery and some near the centre that show dark purple and red staining, indicating their immunoreactivity to both anti-SST-14 and anti-SST-25 sera. Note that the most of the central cells and a group of peripheral cells (arrow) are unstained. B: A high magnification of a portion of one of the islets in (A) revealing the dual coloration of both peripheral and central D cells. Not all peripheral cells are immunostained (arrow). C: The most peripheral cells of this islet immunostain with both anti-aPY (red) and anti-GLU (dark purple). D: An islet has peripheral cells double immunostained with anti-NPY (dark purple) and anti-GLU (red), and one cell that is immunoreactive with only anti-GLU (arrow). Bars: $\mathbf{A}=28 \mu \mathrm{m} ; \mathbf{B}, \mathbf{C}$, and $\mathbf{D}=11 \mu \mathrm{m}$. 


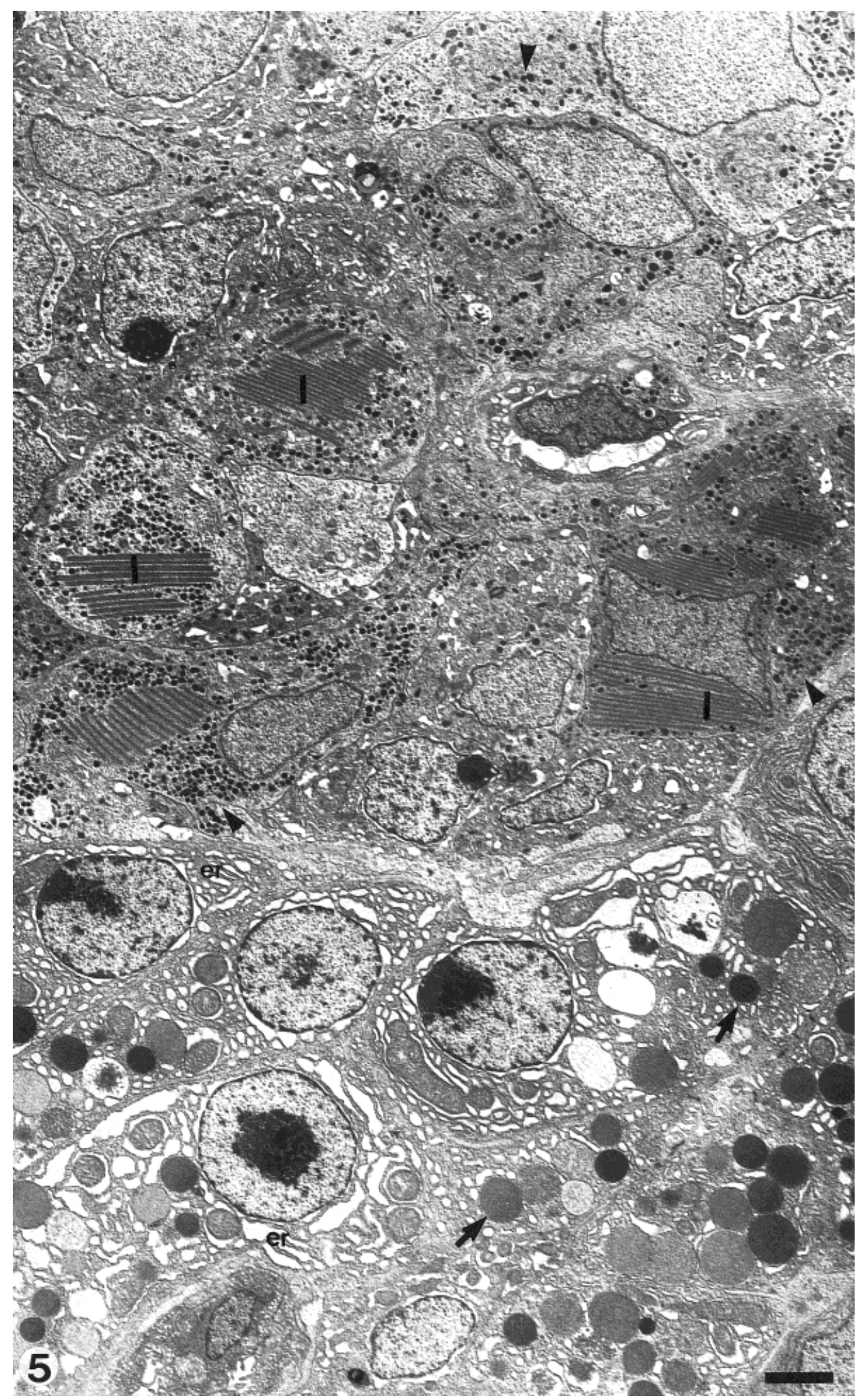

Fig. 5. Low magnification electron micrograph illustrating the close apposition of islet cells and cells of exocrine acini in the pancreas of bowfin (Amia calva). The exocrine cells have large zymogen granules (arrows) of various electron densities and extensive rough endoplasmic reticulum (er). Islet cells have small electron-dense granules (arrowheads) and one cell type has many rod-shaped inclusions in parallel arrays (I). Bar: $2.5 \mu \mathrm{m}$. 
munoreactivity of A cells to anti-GLU was evident by the abundance of cells that were distributed as either a rim (Fig. 3A) or a clump (Fig. 3B) at the periphery of the islets. However, many cells immunoreactive with this antiserum were also located among, and occasionally within, the exocrine acini (Fig. 3A); these cells collectively are henceforth referred to as extra-islet cells. There were fewer cells reacting to anti-GLP in these peripheral locations (Fig. 2E). When double immunolabelling techniques were employed using anti-GLU and anti-NPY or aPY, there was a general colocalised immunoreactivity for glucagon- and PP-family peptides in cells at the periphery of the islets and in the extra-islet population (Fig. 4C,D). However, some cells were only immunoreactive to anti-GLU in the islet (Fig. 4D).

The general impression was that immunoreactivity to the above antisera in the anterior and posterior intestine and stomach was limited to weak staining of a few cells; relative abundance of immunoreactive cell types is compared within each region in Table 1. In the anterior intestine, immunoreactive cells were observed with anti-SST-25, -NPY,PYY, and -GLP (Fig. 2G). In the posterior intestine, immunoreactivity was observed with anti-SST-25 and -GLU. Small numbers of cells in the stomach epithelium were immunoreactive with the SST-25, PYY, GLU, and GLP antisera. The latter two reactions were confined to cells in the gastric glands (Fig. 2F). To test whether our immunohistochemical result of a very low concentration of GEP cells and hormone in the gastrointestinal system was truly reflective of the amount of hormone produced in this region, tissue extracts of intestine were analysed by RIA for the hormones (see below).

\section{Electron Microscopy}

The islet cells had an overall lower electron density than the surrounding exocrine cells (Fig. 5), but the two cell groups were not always clearly demarcated by a capsule of cells or by extracellular matrix (Fig. 5). It was quite common to find islet cells among exocrine cells, and, conversely, a cell with an exocrine profile within an islet. What might be termed "hybrid cells," containing both the large zymogen granules and small electron-dense granules like those present in islet cells, were also commonly found (Fig. 6). The cell membrane of an endocrine cell was often observed directly adjacent to that of an exocrine cell, but cell junctions were rarely encountered (Fig. 7). Cells lining pancreatic ductules also possessed these smaller granules, and the ductular epithelium contained cells that were identical in structure to those seen in islets. The exocrine cells had extensive parallel arrays of rough endoplasmic reticulum and large zymogen (secretory) granules concentrated in the apical cytoplasm. In contrast, all endocrine cells had small, scattered groups of rough endoplasmic reticulum and only small granules dispersed throughout the cytoplasm (Fig. 5).

Several endocrine cell types were tentatively identified based on both their location (observed with a light microscope) relative to immunoreactivity to the various antisera, and on the appearance of their granules (Fig. 8). The most abundant cell, the B cell, occupied most of the central portion of each islet and had mostly spherical granules with flocculent, intensely electron-dense matrices (Fig. 9). The degree to which the granule matrix was separated from its limiting membrane by an electron-opaque region was highly variable within and between cells. However, it was characteristic of B cells to have at least some granules with a loose-fitting membrane (Fig. 9). Extensive pools of glycogen were present in the cytoplasmic matrix and there were usually numerous, often dilated, cisternae of rough endoplasmic reticulum. The second most abundant cell type found throughout the islets, putative D cells, had numerous, densely packed granules with matrices that were of high electron density (Fig. 8). D cell granules were spherical, rod, or oval shaped, and usually had a tight-fitting, limiting membrane (Fig. 10).

The remaining cell types were only present at the periphery of the islet (Figs. 5, 8). One of these had numerous small, mostly spherical granules, and the electron densities of the matrices ranged from low to moderate (Fig. 8). Occasional small granules with a matrix of high electron density and a rod shape were encountered. There were many variations to this cell type, and notable among these was the number of electron-dense inclusions dispersed among the principal granule types. There were no clearly defined cell types at the periphery that could be called A or $\mathrm{F}$ cells based on descriptions of these cells in other vertebrates. Furthermore, we were unable to classify an additional cell type that was characterised by the presence of parallel aggregates of rod-shaped, cytoplasmic inclusions (Figs. 5, 7). These inclusions were composed of a matrix material that appeared to be within cisternae of rough endoplasmic reticulum (Fig. 7). The matrix material was of moderate electron density, relative to the matrix within cytoplasmic granules, and was present as regularly spaced strands that traversed the short axis of the cisternae. The latter arrangement produced a striated pattern throughout the length of each cisternae (Fig. 11). Small fragments of rough endoplasmic reticulum and particulate glycogen were present between the cisternae, which periodically possessed ribosomes. Unlike those of $\mathrm{B}$ and $\mathrm{D}$ cells, the cytoplasmic granules of this cell were of variable electron density and were more uniform in size and shape than in presumed D cells (Fig. 7).

\section{Immunocytochemistry}

The primary purpose of immunogold labelling was to identify the cell type containing the rod-shaped 

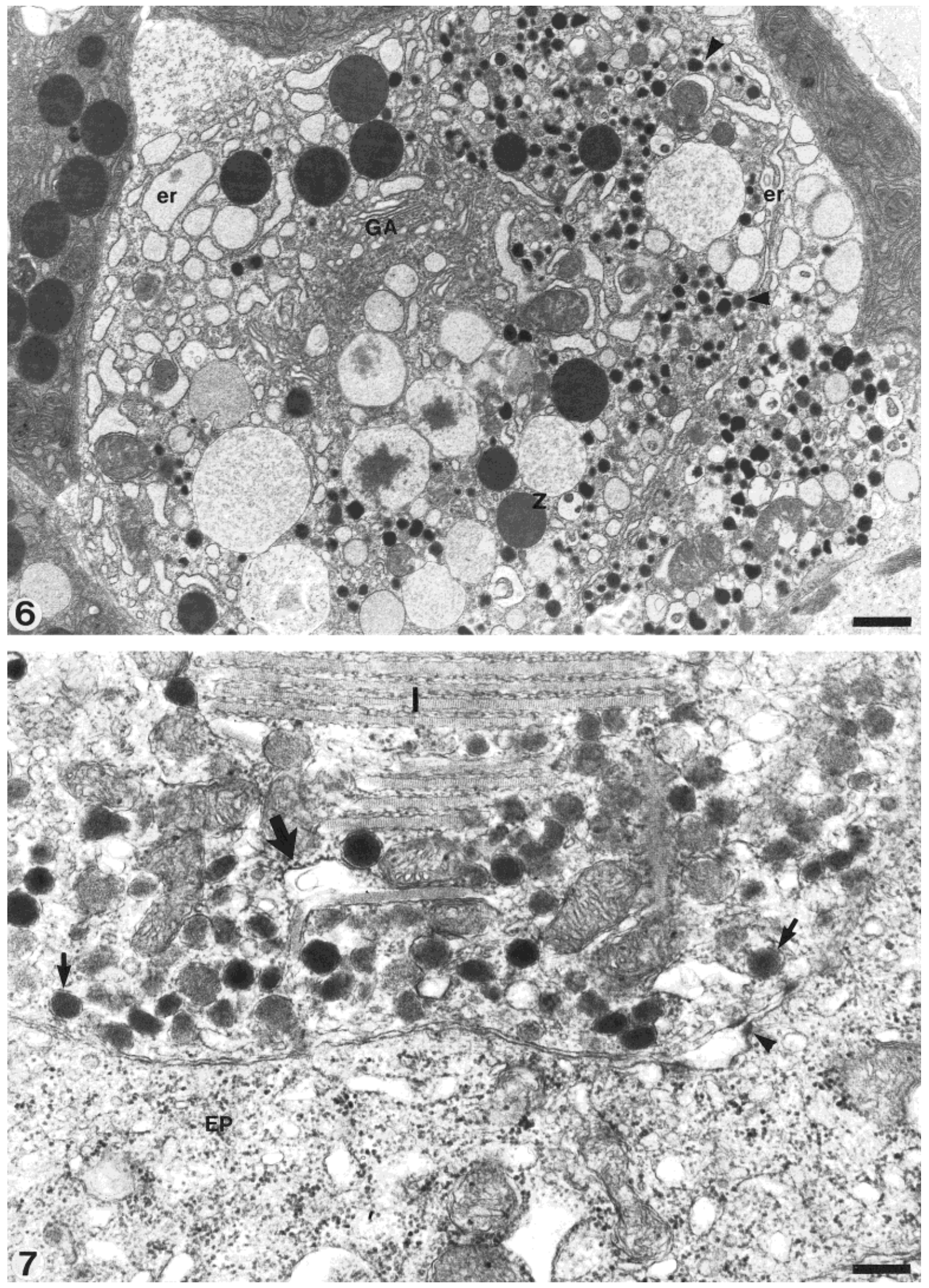
inclusions. Positive immunolabelling was obtained at dilutions ranging from $1: 400$ to $1: 1000$, but 1:500 seemed to provide optimum results (Fig. 12). B cells, with spherical granules of variable size and density, were identified by the localisation of numerous gold particles over these granules and only background levels of particles over mitochondria, rough endoplasmic reticulum, the cytoplasmic matrix, or the nucleus (Fig. 13). Neither a presumed D cell, with more electron-dense and irregularly shaped granules, nor the cell with rod-shaped inclusions, possessed gold particles (Fig. 13). Immunolabelling with antiglucagon occurred over the cell types with the numerous small granules of various electron densities. The gold particles were present over these granules, but not in those of B (Fig. 12) or D cells. In addition, the granules in the cells with the rodshaped inclusions were also immunolabelled with antiglucagon (Fig. 12). Gold particles were not present over the rod-shaped inclusions, the remaining cytoplasm, or the nucleus (Figs. 12, 14). Immunolabelling with either anti-insulin or antiglucagon was not present when the primary antibody was eliminated from the immunocytochemical procedure.

\section{Extracts}

Our previous studies have reported the concentration of the regulatory peptides in the islet organ of bowfin (Conlon et al., 1991a,b, 1993; Wang et al., 1993). In the intestinal regions, NPY/PYY, somatostatin, and glucagon were present in only very low concentrations, corresponding to $<1 \mathrm{pmol} / \mathrm{g}$ tissue.

\section{DISCUSSION}

As noted in a general survey of the pancreas of Actinopterygii (Epple and Brinn, 1975), the pancreatic tissue of the only surviving Amiiformes, the bowfin, is widely distributed in the mesentery connecting the caudal region of the liver, gall bladder, extraheptic bile duct, and the anterior intestine. Throughout most of this area there are pancreatic islets, but exocrine acini that accompany the biliary tree into the liver do not appear to have any associ-

Fig. 6. A cell within a pancreatic acinus of bowfin (Amia calva) has two populations of granules. Zymogen granules (Z) are dispersed among many small electron-dense granules (arrowheads). Also noted are rough endoplasmic reticulum (er) and the Golgi apparatus (GA). Bar: $900 \mathrm{~nm}$.

Fig. 7. An exocrine acinar cell (EP) in bowfin (Amia calva) is apposed to an endocrine cell that contains both small granules of various electron densities (small arrows) and rod-shaped inclusions (I) within membranes of the endoplasmic reticulum (large arrow). Note what appears to be a cell junction between the adjacent cells (arrowhead). Bar: $240 \mathrm{~nm}$. ated endocrine tissue. Because a concentrated area of endocrine cells into Brockmann bodies does not exist in bowfin, we tend to agree with Epple and Brinn (1986), that total isletectomy would virtually be impossible in this species.

Immunoreactivity of specific cell types with heterologous antisera to a variety of regulatory peptides is convincing evidence that the principal cell types found in islets of other fishes, namely A, B, D, and F cells, are present in the pancreas of bowfin. As in islets of many other vertebrates, the most abundant cell is the B cell, which is highly immunoreactive to both antibovine and antilamprey insulin. Immunoreactivity with these two antisera was not surprising because our description of the primary structure of bowfin insulin (Conlon et al., 1991a) revealed a molecule with high sequence homology with pig and lamprey insulin. In fact, there was one common substitution in both lampreys and bowfin (A16) that is unique to these two species. The functional and phylogenetic significance of the primary structure of bowfin insulin has recently been addressed (Conlon, 2000). We recognised the $B$ cells in routine electron microscopy not only by their abundance, but because they contained granules with a loose-fitting membrane, a feature common to B cells of many other vertebrates. Our identification was confirmed through the deposition of gold particles over the granules of this cell type following incubation with antibovine insulin. Although we did not provide quantitative data on the percentage of the islet cell population made up of $\mathrm{B}$ cells, the percentage of this cell type in bowfin is well above the low value of $30 \%$ found in some fishes (Brinn, 1975). However, the apparent high percentage of $B$ cells in bowfin islets must be considered in conjunction with the fact that other endocrine cells in this species are found outside of the islets.

Cells in the islets and in the interstitial tissue surrounding the exocrine acini were immunoreactive with antisera against both salmon glucagon and GLP. Our isolation and description of the primary structure of both glucagon and GLP in bowfin (Conlon et al., 1993), which would have been from tissue samples from both of these sites, explains the strong immunoreactivity of bowfin A cells with the heterologous antisera in the present study. Between salmon and bowfin, only eight amino acids differed in the glucagons and 13 in GLPs. We were unable to provide an explanation for the interstitial distribution of A cells, and could not clearly identify a cell type with fine structural features that has been described for this cell in some other vertebrate species. The peripheral distribution of antiglucagon-immunoreactive cells in fish endocrine islets is also not uncommon (Youson and Al-Mahrouki, 1999). The cell corresponding in position to A cell immunoreactivity was viewed in the electron microscope also to contain rodshaped cytoplasmic inclusions. Furthermore, most, but not all, A cells were immunoreactive with antisera 

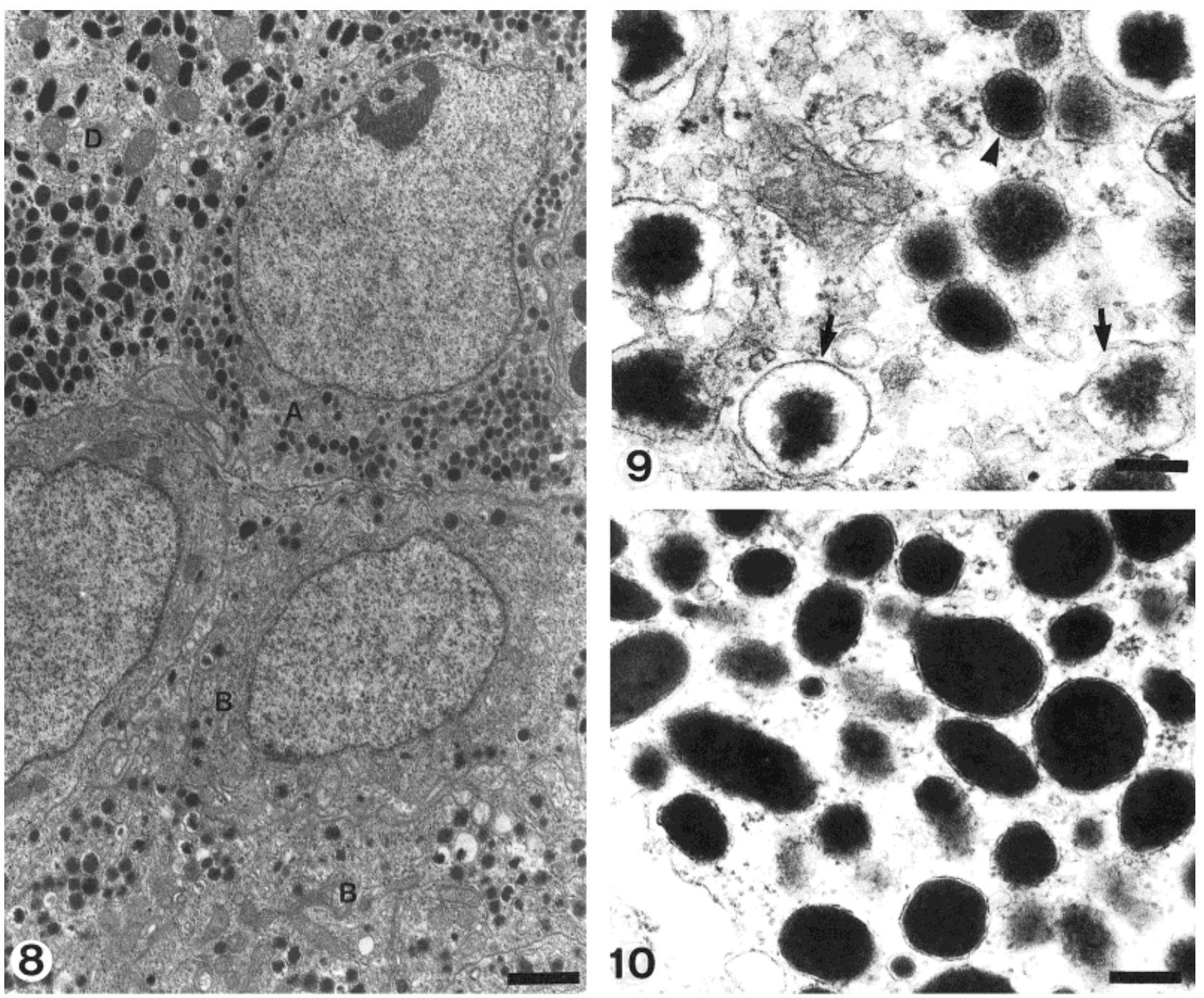

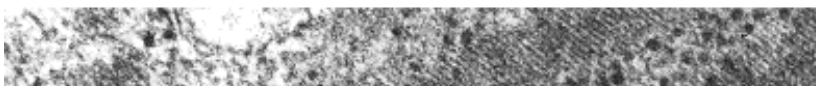

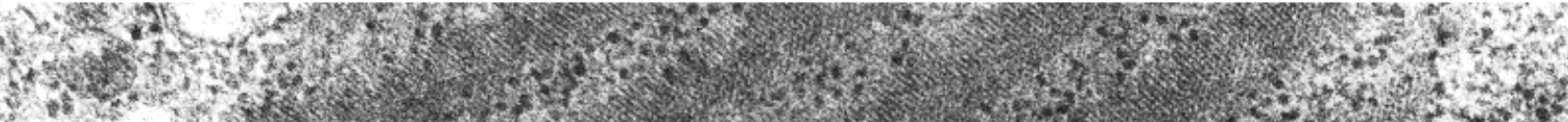

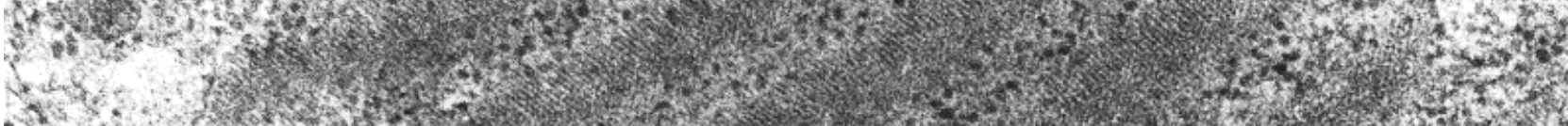

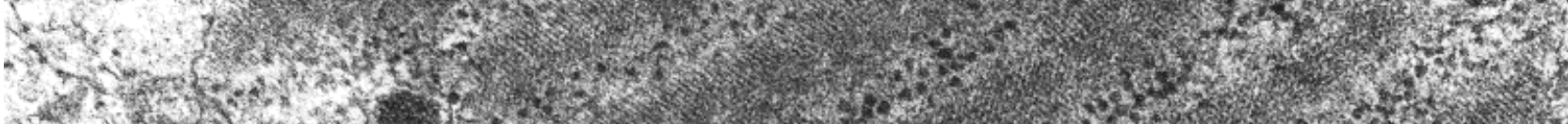

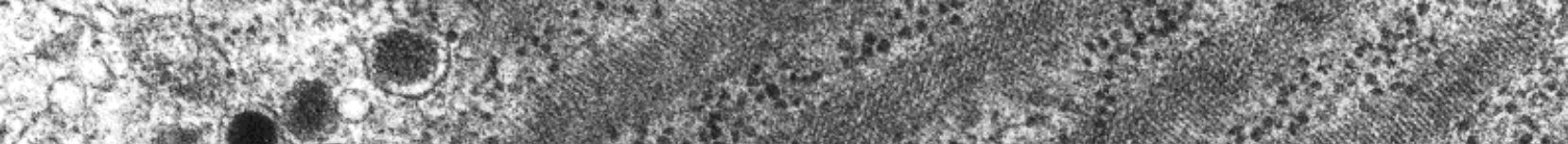

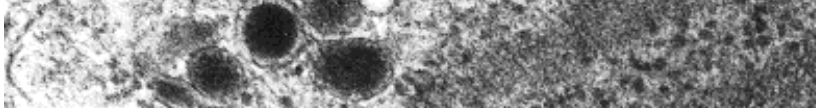

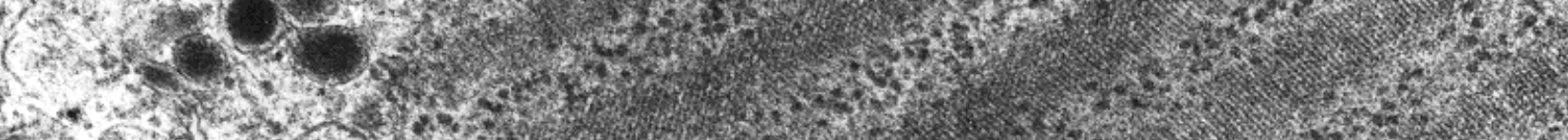

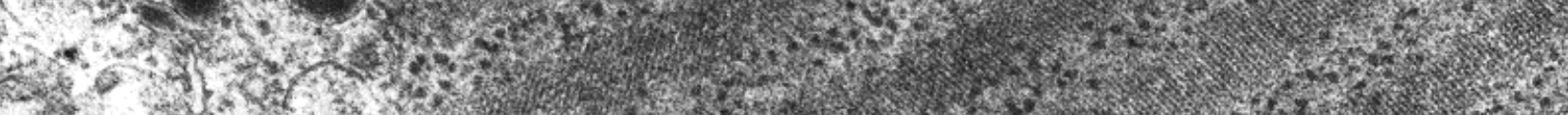

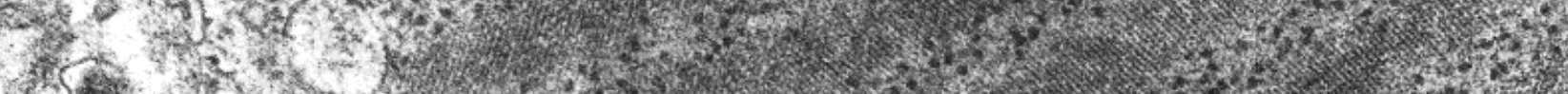

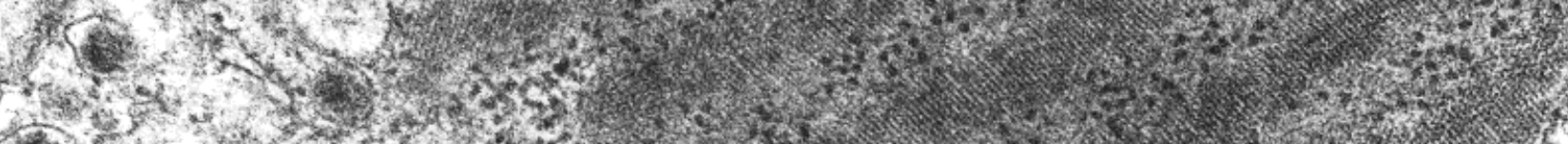

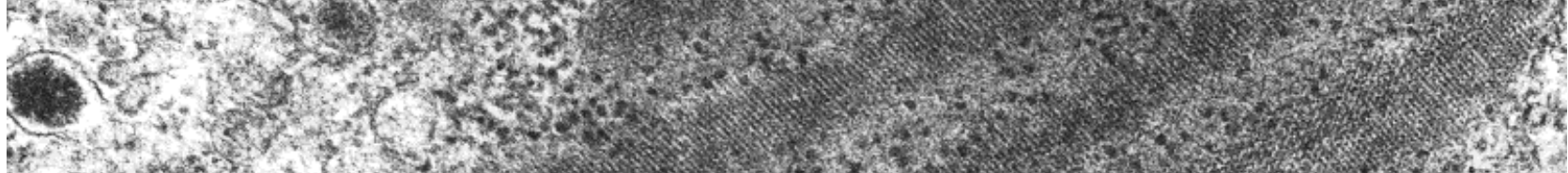
11) 1 (n) 
against PP-family peptides. Both of these features are discussed below.

Extracts of the pancreatic islets of bowfin yielded somatostatins-26 and -14, with the former being the most abundant (Wang et al., 1993). Although the concentration of somatostatin-like immunoreactivity is small in bowfin, relative to that in the pancreatic tissues of other fishes, strong immunoreactivity was visualised in islet cells with the synthetic somatostatin-14 antiserum and against antisalmon SST-25. The distribution of cells immunoreactive to these two antisera did not vary; those reacting to both anti-SST-14 and anti-SST-25 were diffusely distributed among and between B cells and a peripheral population of A and F cells. Double immunolabelling showed immunoreactivity to the two antisera in the same cells. The localisation of these two antisera in different types of $\mathrm{D}$ cells seems to be common among actinopterygian fishes (Nozaki et al., 1988; Abad et al., 1992), but this is not the case in bowfin. The inability to immunostain these D cells with the anti-SST-34 is further evidence for our view that this antibody may be directed against a portion of the extended amino terminal (Youson and Potter, 1993), in which there is virtually no sequence homology between lamprey somatostatin-34 and bowfin somatostatin- 26 . The $\mathrm{D}$ cells could be clearly distinguished from the B cells by their large, irregularly shaped, electron-dense granules with a tightfitting membrane. However, immunocytochemistry at the electron microscope level is required for definitive identification of $\mathrm{D}$ cells, and to establish whether their granules colocate different SST antisera (Agulleiro et al., 1993; Al-Mahrouki and Youson, 1999).

Various antisera that we applied to the pancreas (anti-PP, anti-aPY, anti-NPY) recognised the presence of $F$ cells within both the islets and in the extra-islet tissue around, and occasionally within, the exocrine acini. These cells are the likely source of the NPY-related peptide that we isolated and sequenced from bowfin pancreatic extracts (Conlon et al., 1991b). The bowfin peptide shows a strong sequence homology to porcine NPY, particularly at the

Fig. 8. Low magnification electron micrograph of $\mathrm{B}, \mathrm{D}$, and putative A cells from the pancreatic islet tissue of bowfin (Amia calva). Bar: $1.3 \mu \mathrm{m}$

Fig. 9. Granules of a B cell in bowfin (Amia calva) have an electron-dense matrix surrounded by either a loose-fitting (arrows) or tight-fitting (arrowhead) membrane. Bar: $160 \mu \mathrm{m}$.

Fig. 10. Granules of a D cell in bowfin (Amia calva) have a matrix of high electron density and they are of variable shape. Bar: $200 \mathrm{~nm}$.

Fig. 11. An A cell in bowfin (Amia calva) possesses small granules of variable electron density and many rod-shaped inclusions with a striated matrix. Bar: $160 \mathrm{~nm}$.
$\mathrm{COOH}$-terminal region, but much less sequence similarity with PP or PYY. The fine structural descriptions of $\mathrm{F}$ cells among the pancreata of various vertebrates do not reveal a consistent pattern, but light microscopic immunocytochemistry correlated with adjacent thin sections in Cottus scorpius (Stefan and Falkmer, 1980) revealed a cell type with round granules of moderate electron density. This description is consistent with that for a presumed PP-cell in the shark, Scyliorhinus stellaris (Kobayashi and Ali, 1981). However, we did not recognise a cell type of that description at the periphery of the islet where immunoreactivity for all of PP-family antisera was most intense.

Crystalline inclusions within granules of pancreatic endocrine cells are a common occurrence in almost all vertebrate groups, and often their form is species specific (Lange, 1976). Among the fishes, cube-shaped, hexagonal, and tetragonal profiles have been noted in A cell granules and numerous filaments in F cell granules of teleosts (Kobayashi et al., 1976; Lange and Kobayashi, 1980). Granules with a fibrillar matrix were also reported for B cells in the teleost, Scorpaena scropha (Boquist and Patent, 1971). In the shark, Scyliorhinus stellaris, a presumed A cell has some elongated crystalline structures filled with parallel fibres with a cross periodicity (Kobayashi and Ali, 1981). However, the most spectacular cytoplasmic inclusions in a fish pancreatic endocrine cell are present in hagfish (Boquist and Ostberg, 1975; Raska et al., 1982). The long crystalline profiles described here within the bowfin endocrine cells have a remarkable similarity to the crystalline inclusions reported previously in the presumed B and D cells of hagfish, the only islet cell types present in this species. The similarities include the fact that both hagfish and bowfin inclusions are often seen confined within the cisternae of rough endoplasmic reticulum. Our immunocytochemistry with anti-insulin confirmed that neither the granules nor the inclusions of these cells were immunoreactive with the insulin antibody, and instead the granules of these cells were immunoreactive with anti-GLU. Therefore, we are inclined at this point to view the cell of the bowfin pancreas containing rod-shaped inclusions as an A cell. It is not uncommon for glucagon and pancreatic polypeptide to be localised within the same peripherally located islet cells in fish (Abad et al., 1988; Lozano et al., 1991; Agulleiro et al., 1993; Al-Mahrouki and Youson, 1998, 1999), and this definitely was the case in bowfin. Therefore, we cannot exclude the possibility that the cells containing rod-shaped inclusions might not fall within this same category of $\mathrm{A} / \mathrm{F}$ cell type, like that described for gar (Groff and Youson, 1998). In addition, the first report of these inclusions in hagfish islet cells equated their presence to either an early state of hormone processing or a significant functional state (Raska et al., 1982). In this 

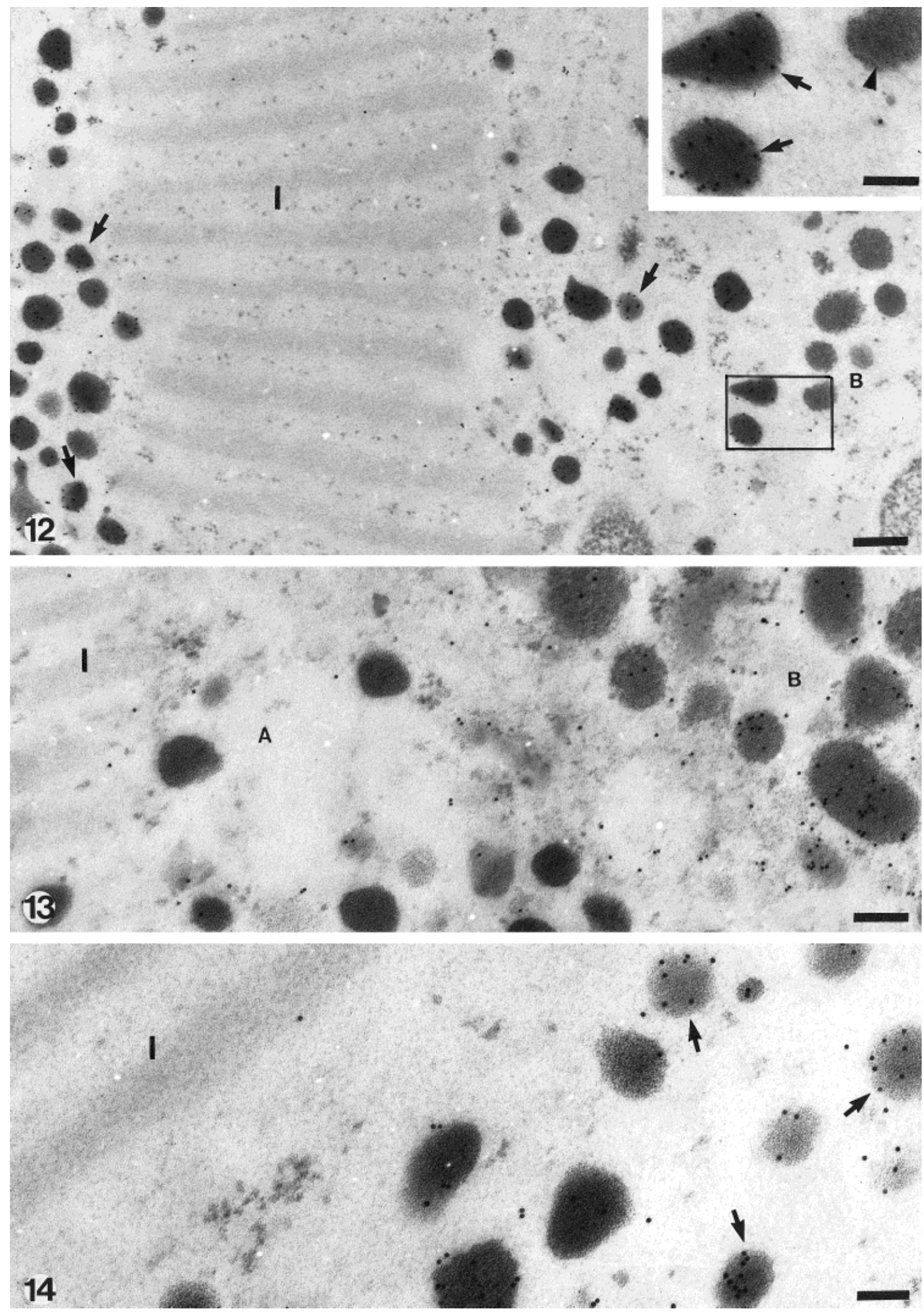

Figures 12-14 
context, it could be interpreted that the inclusions in bowfin were not immunoreactive with anti-GLU because the post-translational processing had not proceeded to a step where antigenic determinants were similar to those in the matrix proteins of the granules. Hagfish and bowfin are two vertebrates that have been described as living fossils, but they have had a divergent evolutionary history. However, one must suspect that this common feature within cells of their islet tissues is more than just a coincidence in the phylogenetic and ontogenetic histories of the islet organ among vertebrates.

The gastrointestinal system of bowfin had a surprisingly low level of immunoreactivity to the antibodies employed. Somatostatin and PP-family cell types were identified in the anterior intestine, somatostatin and glucagon in the posterior intestine, and somatostatin, PP, and glucagon in the stomach. Confirmation of low concentrations of these peptides was provided by RIAs of intestinal extracts. The apparent small number of GEP cells in the gastrointestinal system of bowfin may be compensated for by the many cells that are present in the extra-islet areas of the pancreas of this species. The functional significance of such an arrangement is not clear. In fact, Epple and Brinn (1986) claim that the exocrine-endocrine relationship in the pancreas has no functional significance. Therefore, the extra-islet endocrine cells (between and within acini) may be a consequence of ontogenetic differences between bowfin and other actinopterygians. As in other vertebrates, the exocrine and islet portions of the fish pancreas have a common origin from endoderm of the early foregut (for review see Youson and Al-Mahrouki, 1999). Incomplete isolation of these two pancreatic components could result in multiple sites for endocrine cells, in contrast to what is ordinarily the case in actinopterygians. A precedent for multiplicity of endocrine tissues in bowfin relative to other Actinopterygii is seen in the kidney, where corpuscles of Stannius are 100-fold those of other ray-finned fishes (Youson et al., 1976).

Figs. 12-14. Immunocytochemical preparations using the protein A-gold technique on unstained sections from bowfin (Amia calva) islet tissue.

Fig. 12. Granules within an A cell (arrows), but not the rodshaped inclusions (I), are immunolabelled following incubation with anti-GLU. Granules of a B cell (B) are not labelled. Bar: 400 $\mathrm{nm}$. Inset: High magnification of A (arrows) and B (arrowhead) granules in boxed area. Bar: $140 \mathrm{~nm}$.

Fig. 13. Anti-insulin immunostained granules of a $\mathrm{B}$ cell but not those of an A cell with rod-shaped inclusions (I). Bar: $190 \mathrm{~nm}$.

Fig. 14. Anti-GLU immunostained A cell granules (arrows), but not the rod-shaped inclusions (I). Bar: $140 \mathrm{~nm}$.

\section{ACKNOWLEDGMENTS}

The authors thank Luciano Marra for his assistance in animal collection and maintenance, and Natasha Begg, Ana Goncalves, and Fariba Sam for their contributions in the early stages of the study.

\section{LITERATURE CITED}

Abad ME, Taverne-Thiele JJ, Rombout HWM. 1988. Immunocytochemical and ultrastructural characterization of coexistence of pancreatic polypeptide and glucagon-like immunoreactivity in the pancreatic endocrine cells of Sparus auratus L. (Teleostei). Gen Comp Endocrinol 70:9-19.

Abad ME, Garcia Ayala A, Lozano MT, Agulleiro B. 1992. Somatostatin-14- and somatostatin-25-like peptides in pancreatic endocrine cells of Sparus auratus (Teleost): A light and electron microscopic immunocytochemical study. Gen Comp Endocrinol 86:445-452.

Agulleiro B, Lozano MT, Abad ME, Garcia Hernandez MP. 1993. Electron-microscopic immunocytochemical study of the endocrine pancreas of sea bass (Dicentrarchus labrax). Cell Tissue Res 274:303-314.

Al-Mahrouki AA, Youson JH. 1998. Immunohistochemical studies of the endocrine cells within the gastro-entero- pancreatic system of osteoglossomorpha: An ancient teleostean group. Gen Comp Endocrinol 110:125-139.

Al-Mahrouki AA, Youson JH. 1999. Ultrastructure and immunocytochemistry of the islet organ of Osteoglossomorpha (Teleostei). Gen Comp Endocrinol 116:409-421.

Bendayan M. 1989. Protein A-gold and protein G-gold postembedding immunoelectron microscopy. In: Hayat MA, editor. Colloidal gold-principles, methods and applications, Vol 1. San Diego: Academic Press. p 33-94.

Boquist L, Ostberg Y. 1975. Annulate lamellae and crystalline inclusions in granular endoplasmic reticulum of the islet organ and associated tissues of a cyclostome, Myxine glutinosa. Cell Tissue Res 158:75-87.

Boquist L, Patent G. 1971. The pancreatic islets of the teleost Scorpaena scropha: An ultrastructural study with particular regard to fibrillar granules. Z Zellforsch 115:416-425.

Brinn JE Jr. 1975. The pancreatic islet cytology of Ictaluridae (Teleostei). Cell Tissue Res 162:357-365.

Cheung R, Plisetskaya EM, Youson JH. 1990. Distribution of two forms of somatostatin in the brain, anterior intestine and pancreas of adult lampreys (Petromyzon marinus). Cell Tissue Res 262:283-292.

Conlon JM. 1995. Peptide tyrosine-tyrosine (PYY)—An evolutionary perspective. Am Zool 35:466-473.

Conlon JM. 2000. Molecular evolution of insulin in nonmammalian vertebrates. Am Zool 40:200-212.

Conlon JM, Thim L. 1985. Primary structure of glucagon from an elasmobranchian fish, Torpedo marmorata. Gen Comp Endocrinol 60:398-405.

Conlon JM, Youson JH, Whittaker J. 1991a. Structure and receptor-binding activity of insulin from a holostean fish, the bowfin (Amia calva). Biochem J 276:261-264.

Conlon JM, Bjenning C, Moon TW, Youson JH, Thim L. 1991b. Neuropeptide Y-related peptides from the pancreas of a teleostean (eel), holostean (bowfin) and elasmobranch (skate) fish. Peptides 12:221-226.

Conlon JM, Youson JH, Mommsen TP. 1993. Structure and biological activity of glucagon and glucagon-like peptide from a primitive bony fish, the bowfin (Amia calva). Biochem J 295: 857-861.

Elbal MT, Lozano MT, Agulleiro B. 1988. The endocrine cells in the gut of Mugil saliens Risso, 1810 (Teleostei): An immunocytochemical and ultrastructural study. Gen Comp Endocrinol 70:231-246.

Epple A, Brinn JE. 1975. Islet histophysiology: evolutionary correlations. Gen Comp Endocrinol 27:320-349. 
Epple A, Brinn JE. 1986. Pancreatic islets. In: Pang PKT, Schreibman MT, editors. Vertebrate Endocrinology: Fundamentals and Biomedical Interpretations, Vol 1, Morphological Considerations. Orlando: Academic Press. p 279-317.

Falkmer S. 1985. Comparative morphology of pancreatic islets in animals. In: Volk BW, Arguilla ER, editors. Diabetic Pancreas, 2nd ed. New York: Plenum Press. p 17-52.

Gardiner BG, Maisey JG, Littlewood DTJ. 1996. Interrelationships of basal neopterygians. In: Stiassny MLJ, Parenti LR, Johnson GD, editors. Interrelationships of fishes. San Diego: Academic Press. p 117-146.

Groff KE, Youson JH. 1997. An immunohistochemical study of the endocrine cells within the pancreas, intestine and stomach of the gar (Lepisosteus osseus L.). Gen Comp Endocrinol 106:116.

Groff KE, Youson JH. 1998. Fine structure and immunocytochemistry of cells within the endocrine pancreas of the gar (Lepisosteus osseus). Can J Zool 76:6-18.

Kobayashi K, Ali SS. 1981. Cell types of the endocrine pancreas in the shark Schliorhinus stellaris as revealed by correlative light and electron microscopy. Cell Tissue Res 215:475-490.

Kobayashi K, Shibasaki S, Takahashi Y. 1976. Light and electron microscopic study on the endocrine cells of the pancreas in a marine teleost Fugu rubripes rubripes. Cell Tissue Res 174: 161-182.

Lange RH. 1976. Crystallography of islet secretory granules-A contribution to the problem of chemical composition of secretory granules. In: Fujita T, editor. Endocrine gut and pancreas. Amsterdam: Elsevier Science Publishing. p 167-178.

Lange RH, Kobayashi K. 1980. Cubic crystals in the endocrine pancreatic A-cells of a teleost, Fugu rubripes (Temminck and Schlegel, Tetraodontidae). J Ultrastruct Res 72:20-26.

Larhammar D. 1996. Evolution of neuropeptide Y, peptide YY and pancreatic polypeptide. Regul Pept 62:1-11.

Lozano MT, Ayala AG, Abad ME, Agulleiro B. 1991. Pancreatic endocrine cells in sea bass (Dicentrarchus labrax L.): I. Immunocytochemical characterization of glucagon- and PP-related peptides. Gen Comp Endocrinol 81:187-197.

McIntosh C, Arnold R, Bothe E, Becker H, Kobberling J, Creutzfeldt W. 1978. Gastrointestinal somatostatin: extraction and radioimmunoassay in different species. Gut 19:655-663.

Nozaki M, Miyata K, Oota Y, Gorbman A, Plisetskaya EM. 1988. Different cellular distributions of two somatostatins in brain and pancreas of salmonids, and their associations with insulinand glucagon-secreting cells. Gen Comp Endocrinol 69:267280 .

O'Hare MMT, Schwartz TW. 1989. Expression and precursor processing of neuropeptide $\mathrm{Y}$ in human pheochromocytoma and neuroblastoma tumors. Cancer Res 49:7010-7014.

Plisetskaya EM, Mommsen TP. 1996. Glucagon and glucagon-like peptides in fishes. Int Rev Cytol 168:187-257.

Plisetskaya EM, Pollock HG, Rouse JB, Hamilton JW, Kimmel JR, Gorbman A. 1985.

Characterization of coho salmon (Oncorhynchus kisutch) insulin. Regul Pept 11:105-116.

Plisetskaya EM, Pollock HG, Elliott WM, Youson JH, Andrews PC. 1988. Isolation and structure of lamprey (Petromyzon marinus) insulin. Gen Comp Endocrinol 69:46-55.

Raska I, Titlbach M, Boquist L, Emedin SO, Falkmer S. 1982. Optical diffraction analysis of crystalline inclusions in the rough endoplasmic reticulum of islet parenchymal cells of the hagfish, Myxine glutinosa. Cell Tissue Res 225:461-464.

Stefan Y, Falkmer S. 1980. Identification of four endocrine cell types in the pancreas of

Cottus scorpius (Teleostei) by immunofluorescence and electron microscopy. Gen Comp Endocrinol 42:171-178.

Sternberger LA, Hardy PH Jr, Cuculis JJ, Meyers HG. 1970. The unlabelled antibody enzyme method of immunohistochemistry. Preparation and properties of soluble antigen-antibody complex (horseradish peroxidase anti-horseradish peroxidase) and its use in the identification of spirochetes. J Histochem Cytochem 18:315-333.

Wang Y, Youson JH, Conlon JM. 1993. Prosomatostatin-I is processed to somatostatin-26 and somatostatin-14 in the pancreas of the bowfin, Amia calva. Regul Pept 47:33-39.

Youson JH, Al-Mahrouki AA. 1999. Ontogenetic and phylogenetic development of the endocrine pancreas (islet organ) in fishes. Gen Comp Endocrinol 116:303-335.

Youson JH, Potter IC. 1993. An immunohistochemical study of enteropancreatic endocrine cells in larvae and juveniles of the southern hemisphere lampreys Geotria australis and Mordacia mordax. Gen Comp Endocrinol 92:151-167.

Youson JH, Butler DG, Chan ATC. 1976. Identification and distribution of the adrenocortical homolog, chromaffin tissue, and corpuscles of Stannius in Amia calva L. Gen Comp Endocrinol 29:198-211. 